\title{
ONE-STOP SERVICE SYSTEM TO IMPROVE PUBLIC SERVICES
}

\author{
Djatmiko Hary \\ Supreme Court of Republic of Indonesia \\ E-mail: harydj@gmail.com
}

\begin{abstract}
In terms of licensing, one technical step to improve the quality of community services is through the establishment of an Integrated Service Unit using a one-stop service system. This study focuses on the process of licensing service mechanism, the quality of public services (in terms of licensing), the supporting factors, and the obstacles of improving public services (in terms of licensing) by using a one-stop service system. The findings show that:1)With this system, the applicant only needs to submit an application file and take the completed license or accept the refusal of the application if it does not fulfill the technical requirement through the available counterat the Licensing Service Office;2)The use of a onestop service system provides a convenience to the community in the process of license management. However, this has not been able to fully improve the quality of public services especially in ensuring the time and cost of licensing;3)The supporting factors to improve public services (licensing) by using a one-stop service system are the high commitment and sincerity of regional leaders;4) Last but not least,the coordination with relevant agencies, inadequate facilities, and infrastructure, as well as employee's mental attitudes and skills are the inhibiting factors in this matter.
\end{abstract}

\section{KEY WORDS}

Public services, integrated service unit, good government.

The function of the government in its development has indeed undergone a paradigm development. Referring to the history of the state, the social contract between citizens and the government as the executor of the social contract is a classic form of service duties carried out today. We can see the development of this paradigm from the point of demands for changes in government functions. If at first the government is only required to carry out the implementation of state functions and duties, then with many demands, the globalization changes and challenges have an impact on the changes of government functions. This day, the government is also demanded as a good service provider in addition to other state functions (agent of development). Therefore, the current demand that arises is the creation of good government.

The good government itself leads to the achievement of the government to implement excellent state functions and public services. The implementation of state functions is realized in the form of the realization of development programs that have been formulated. In this context, development is not only in terms of physical development but also non-physical development. On the other hand, public services are realized by providing quality services to the community. This service is not only related to basic administrative services such as KTP (ID card), SIM (Driving License), certificates, and etc. but more on the service of community basic needs. Good Local Government becomes a very possible thing to be realized. The local government is very responsive in reading the needs of the community which is then realized in an aspirational development program.

This does not mean that in order to make it happen, there is no challenge. Chapman and Cleveland in Redioka (2001) said that, in the future, there are four major forces that can be seen as challenges to public services, namely: a) the pressure on centralization and decentralization, b) the work unions in public services, c) the increasing community involvement, and d) the strong influence of technological change.

Meanwhile, the implementation of public services carried out by government officials in various service sectors related to the fulfillment of civil rights and basic needs is still 
considered not fully in accordance with the demands and expectations of the community. Various service weaknesses that often become the talk of the public and the business community involve service procedures that are still complicated, not transparent, less informative, less accommodating, and less consistent so as not to guarantee legal certainty as well as time and costs efficiency. This also generates brokering practices, illegal fees, thuggery, and indications of corruption.

The weaknesses of these services must be solved as soon as possible because we still experiencing various multidimensional crises in this era of free trading and because of the increasing demands from society and the business community to increase the quality of public services. The perception of the public towards public services has changed drastically; a good service is a full right of the community that must be answered by the government officials by carrying out their duties responsibly in order to provide excellent service. Therefore, the adoption of a new paradigm in providing democratic, transparent, and accountable services must always be improved and supported together with full commitment and spirit from all levels of government officials at the Central and Regional level, from the leaders to the leading executors.

The same thing is also stated by Kristiadi (1994) that in order to overcome the bad image of the bureaucracy and to prepare the bureaucracy to face the globalization flow which can rapidly change the social environment of the community, there are a number of things that need to be taken into account by the bureaucracy to anticipate these changes; the bureaucracy must be balanced with organizational improvements thus it is characterized by a modern, lean, effective, and efficient organization which also able to distinguish the tasks that need to be handled by the bureaucracy and the tasks that can be handed over to the community; The system of work procedures must be in accordance with the characteristics of a modern organization which are fast, precise, and accurate by maintaining the quality, cost, and timeliness in the production process. Based on the above background, the problem of this study can be summarized as follows: What are the supporting and inhibiting factors in improving public services? Therefore, the purpose of this research is to find out and analyze the supporting and inhibiting factors in improving public services.

\section{METHODS OF RESEARCH}

This study used a qualitative approach with a view to discover, understand, explain, and get a picture of the one-stop service system in improving public services in terms of licensing. Based on the problems and objectives that have been formulated above, the focus of this research is the supporting and inhibiting factors in improving public services at the Licensing Service Office.

In accordance with the problem and focus of this research, the data sources are as follows: This is a qualitative research so that the sampling technique is done purposively (purposive sampling). The selection of informants is based on the subject I who controls the problem has the data and is willing to provide the data. Whereas, the informants are selected according to the objectives and research topics. This method is called "Snow Ball Sampling". The last informant is chosen based on data saturation where there is no more variation in the information provided by the informant. In this study, the selection of informants is adjusted to the main tasks and functions of each selected informant that is related to the implementation of a one-stop service system at the Licensing Service Office. Therefore, a precise and indepth data on the research topic can be obtained at the end of the research. Besides that, a qualitative data analysis was also used as proposed by Milles and Hubermann (1992) with several procedures such as data reduction, data display, and drawing a conclusion or data verification.

Supporting and InhibitingFactorsin Improving Public Services. In order to improve public services at the Licensing Service Office of Kendari, there are a number of things that can support the efforts to improve the services provided to the community, some of which are: the support and commitment from the Regional Government; the Licensing Service Offices are not used as a major source of increasing local revenue. 
In an effort to improve the licensing services to the public, the Licensing Service Office still faced several obstacles. Some of those are: the coordination with relevant agencies in licensing issues; the employees' mental attitudes and technical skills; the facilities and infrastructure

\section{DISCUSSION OF RESULTS}

Licensing is an instrument of government policy to control the negative externalities that may be caused by social and economic activities. The license is also an instrument to allocate public goods efficiently and fairly. It prevents information asymmetry and protects the legality for ownership or operation of activities. (Suhirman, 2002). Considering the central function to prevent market failure from individual activities, it is clear that the function of a license is a regulatory function that must be held by the government.

The licensing services from the government in the Decree of the Ministry of Administrative and Bureaucratic Reform of the Republic of Indonesia number 63 of 2003 as administrative service group said that a service that produced various forms of official documents is needed by the public. As a state administrative decision that contains activities that can or cannot be done by the community, the government needs and has an organization called as bureaucracy. Associated with the context of the Indonesian government, Priyo Budi Santoso (1997) defined bureaucracy as a whole government organization which carries out the tasks of the state in various government organizational units under departmental institutions and non-departmental institutions both at the center and in the regions. There are three categories of bureaucratic organizations. The first category is the general government bureaucracy that carries out the regulation. The second category is the bureaucracy that provides public services. The third category is the development bureaucracy which is a government organization that runs one specific field to achieve the goal of state development such as government organizations engaged in agriculture, industry, education, and others. In the practice, licensing in Indonesia is categorized as a service provider so that it is done by a bureaucracy that provides public services.

The general public and the business community often complain that the process of licensing delivered by the government is complicated, not transparent, and needs extra costs. They often go back and forth from one office to another just to manage the licensing service. This makes the community to feel like being played by the government officials so that the overall performance of public services is bad. In the business community, the problem is known to come from the lack of clarity in procedures as well as time and costs so that the costs incurred are ultimately high. In addition, this condition causes the public to have less trust in the government.

Developing integrated services is believed to be one of the steps to resolve licensing issues that have been complained of by the public. However, to form an Integrated Service Office with one-stop and one-door service pattern, Rustiani (2001) proposed that it needs a commitment from the Regional Government (officials) by formulating a Regent/Mayor's Decree or Regional Regulation in regards to the formation of Technical Implementation Unit. This can be an indicator that the Regional Government takes this issue seriously. The commitment from the Regional Government also can be proved through the policy of Regional Budget allocation to finance the establishment of the Technical Implementation Unit and its duties.

\section{CONCLUSION AND SUGGESTIONS}

From the study and analysis of this research (One-Stop Service System to Improve Public Services), the conclusions can be drawn as follows: the use of a one-stop service system provides a convenience to the community in the process of obtaining a license. However, it has not been able to fully solve the problem of time and costs delays in the process. To measure the quality of licensing services provided, there are some criteria such as a) simplicity, b) clarity, c) timeliness, d) accuracy, e) security, f) responsibility, g) 
completeness of facilities and infrastructure, h) ease of access, i) discipline, courtesy, and friendliness, and j) hospitality to see how far the principles of public services are applied in the provision of public services.

To improve public services in terms of licensing, it can take advantage from the support provided by the City Government with the commitment from the Regional Government (officials) shown in its legal products such as the Mayor's Decree and Regional Regulations. Besides that, the Licensing Service Office is not used as a source of Local Revenue but as an accelerator of economic growth. In this effort, there are some obstacles such as the coordination with relevant agencies, inadequate facilities, and infrastructure, as well as the mental attitudes and skills of the employees.

Based on the conclusions of the research as stated above, it is suggested that: the simplification of the licensing process through a one-stop service system still needs to be followed by a simplification in terms of technical and administrative requirements. In correlation with that, the conditions submitted must be really relevant to the license; improving the coordination and unifying the visions/missions between relevant institutions in the process of license arrangement. In order to get the same views on licensing issues so as to eliminate the sectorial-ego on each agency, it needs to; focus on developing human resources so that the employees can have adequate mental attitudes and technical skills thus they can provide good service to the community. This also can be done by registering them to the public service training programs and conducting comparative studies in other regions that are successful in implementing a one-stop service system.

\section{REFERENCES}

1. Alwasilah, C.A. 2002. Pokoknya Kualitatif: Dasar-dasar merancang dan melakukan penelitian kualitatif.Jakarta: PT Dunia Pustaka Jaya.

2. Aprillilik, S. 2002. Implementasi Program UPT Bidang Perizinan di Kabupaten Pasuruan. Postgraduate Program, Universitas Brawijaya.

3. Atamaja, AK. 2002. Kualitas Pelayanan Publik di Unit Pelayanan Terpadu. MAP. Universitas Gajah Mada. Yogyakarta.

4. Bertens, K. 2000. Etika: Seri Filsafat Atma Jaya. PT Gramedia Pustaka Utama. Jakarta.

5. Denhardt, Kathryn G. 1988. The Ethics of Public Service. Greenwood Press. Wesport.

6. Dwiyanto, Agus. 2002. Reformasi Birokrasi Publik di Indonesia. Pusat Studi Kependudukan dan Kebijakan. Universitas Gajah Mada . Yogyakarta.

7. Dirjen Pemerintah Umum Depdagri. 2004. Modul Pengembangan Kelembagaan Pelayanan Terpadu Satu Atap/Satu Pintu.Jakarta

8. 2004. Modul Pelayanan Prima Lembaga Pelayanan Terpadu Satu Atap/Satu Pintu. Jakarta.

9. 2002. Draft Pedoman Umum.Lembaga Pelayanan terpadu Satu Atap (LPTSA). Jakarta.

10. Effendi, Sofian. 1995. Kebijakan Pembinaan Organisasi. Penerbit Erlangga. Jakarta.

11. Gaspersz, V. 1994. Manajemen Kualitas. Gramedia. Jakarta.

12. Handayaningrat, Soewarno. 1985. Pengantar Studi Ilmu Administrasi dan Manajemen. Gunung Agung. Jakarta.

13. Henry, Nicholas. 1995. Public Administration and Public Affairs. Sixth Edition. Engelwood.

14. Ingstrup, Ole and Crookall. 1999. The Three Pillars of Public Management, Secret of Sustained Succes.McGill-Queen's University Press. Montreal \& Kingston. London.

15. Keban, Y. T. 2001. Etika Pelayanan Publik: Pergeseran paradigma, dilema dan implikasinya bagi pelayanan publik di Indonesia. Majalah Perencanaan Pembangunan, 24. Bappenas. Jakarta.

16. Kristiadi, J.B. 1994. Revitalisasi Birokrasi dalam Meningkatkan Pelayanan Prima. Bisnis dan birokrasi. Jurnal IImu Administrasi \& Organisasi,3(II), September 1994. Universitas Indonesia.

17. Lembaga Administrasi Negara. 2003. Sistem Administrasi Negara Republik Indonesia. Perum Percetakan Negara RI. Jakarta. 
18. Lincoln, Y. S and Egon G. G. 1985. Naturalistic Inquiry. Beverly Hills, Sage Publication.

19. Lovelock, Christopher. 1994. Product Plus: How to Product + Service Competitive Advantages. Mc Graw Hill. New York.

20. Moleong, Lexy. 2002. Metodologi Penelitian Kualitatif. Remaja Rosdakarya. Bandung.

21. Moenir, H.A.S. 1998. Manajemen Pelayanan Umum di Indonesia. Bumi Aksara. Jakarta.

22. Moerdiono. 1992. Birokrasi dan Administrasi Pembangunan: Beberapa pemikiran Pemecahan. Sinar Grafika. Jakarta.

23. Musgrave, R.A and Musgrave, P.B. 1991. Keuangan Negara dalam Teori dan Prospek. Penerbit Erlangga. Jakarta.

24. Nazir, Mohammad. 1988. Metode Penelitian. Ghalia Indonesia. Jakarta.

25. Neuman, Lawrence W. 1994. Social Research Method: qualitative and quantitative approaches. Allyn and Bacon A Division of Simon \& Schuster, Inc. Needham Heights. Massachusetts.

26. Noor, Irwan. 2001. Mensoalkan: Makna Haqiqi Pelayanan Publik. Jurnal Administrasi Negara, 1(2), Universitas Brawijaya.

27. Osborne, David and Ted Gaebler. 2000. Mewirausahakan Birokrasi: Reinventing Government. Pustaka Binaman Pressindo. Jakarta.

28. Perry, James L. 1989. Hand Book of Public Administration. CA: Jossey-Bass limited. San Francisco.

29. Pusat Studi Pengembangan IPB. 2004. Review of One Stop Shops in Indonesia. A study on one stop shops' legal status and authority, performance, impact on bussiness environment and assessment of external support. Laporan Penelitian. Institut Pertanian Bogor.

30. Rasyid, Ryaas. 1998. Desentralisasi Dalam Menunjang Pembangunan Daerah dalam Pembangunan Administrasi Indonesia. LP3ES. Jakarta.

31. Redioka, N.A. 2001. Pelayanan Publik pada Unit Pelayanan Terpadu Kota Denpasar. Postgraduate Program, Universitas Brawijaya.

32. Robbins, S,P. 1995. Managing Organizational Conflict: A non-traditional approach. Engelwood cliffs. NJ: Prentice Hall.

33. Rondinelli, Dennis A. 1981. Decentralization in Developing Countries: A review of Recent experience. World Bank Staff. Working Papers. Washington.

34. Rustiani, F. 2001. Perizinan Usaha Kecil di Indonesia. Laoran Penelitian. TAF-USAID.

35. Sedarmayanti. 2004. Good Governance (Kepemerintahan yang baik) jilid 2. Penerbit Mandar Maju. Bandung.

36. Sobana, Achmad. 1999. Pola Pelayanan Umum Satu Atap: Suatu upaya mempercepat proses perizinan investasi. Rineka Cipta. Bandung.

37. Starling, Grover. 1998. Managing Public Sector. School of Business and Public Administration: University of Houston : Clear Lake Hart Court College Publisher. USA.

38. Steer, Richard, M. 1985. Efektifitas Organisasi. Penerbit Erlangga. Jakarta.

39. Suhirman, 2002. Merancang Kebijakan Perijinan Yang Pro Pasar dan Sensitif pada Kepentingan Publik, USAID Research Report.

40. Susanto, A. 2000. Evaluasi Dampak Implementasi Kebijakan Pelayanan Publik (kajian tentang kebijakan perizinan moedl satuan administrasi satu atap di Kabupaten Nganjuk). Program Pasca Sarjana Universitas Brawijaya. Malang.

41. Suwondo. 2001. Desentralisasi Pelayanan Publik: Hubungan komplementer antara sektor negara, mekanisme pasar dan organisasi non-pemerintah. Jurnal Administrasi Negara, 1(2), March. Universitas Brawijaya.

42. Tjiptono, F. 1995. Strategi Pemasaran. Andi Offset. Yogyakarta.

43. Winarno, B. 2002. Teori dan Proses Kebijakan Publik. Penerbit Media Pressindo. Yogyakarta.

44. Zauhar, S. 2001. Administrasi Pelayanan Publik: Sebuah perbincangan awal. Jurnal IImu Administrasi Negara. Vol. 1 No. 2 Maret 2001. FIA Universitas Brawijaya. Malang.

45. Zeithaml, V. A., Parasuraman, A., \& Berry, L. L. (1990). Delivering quality service: Balancing customer perceptions and expectations. Business (pp. 54-59). New York, N.Y: The Free Press. https://doi.org/10.1177/0001699303046002008. 